\author{
Goran Kasum* \\ Gligorov Strašo** \\ Tanja Nastasić-Stošković*** \\ *Faculty of Sport and Physical Education, University of Belgrade \\ **SVR Skoplje, Skoplje, Makedonija \\ ***Kliničko-bolnički centar „Dr Dragiša Mišovićc“, Beograd
}

796.8-056-26

Professional paper

\title{
COMBAT SPORTS FOR PERSONS WITH DISABILITIES
}

\begin{abstract}
In literature, the term adapted sport indicates sports activities, modified and adapted to persons with disabilities. In spite of their highly prominent values, combat sports are underrepresented among persons with disabilities in Serbia. The benefits of combat sports practicing are numerous, and at some international hospitals, martial sports and arts already have an important role in the treatment of traumatized and disabled persons. Currently, the programme of Paralympic Games includes only two sports, these are fencing and judo, in male and female competition. Almost certainly, karate will also be included in the programme of Paralympic Games, and there are similar ambitions in the case of taekwondo as well. In addition to these sports, some martial arts, especially aikido, thai-chi-chuan and qigong, have obtained significant representation and interest among persons with disabilities. The reasons for weaker interest in other martial sports and arts, should be sought in the fact that they are underrepresented among this population, and that these persons are not offered the possibility of organized practice of such sports. Orientation towards a combat sport brings great refreshment and powerful emotional experience to each practitioner, and this fact has special significance to persons with disabilities. In Serbia, combat sports are not widely represented among persons with disabilities, and only the wrestlers with impaired hearing have achieved significant success on the international stage. On the other hand, the popularity of combat sports among persons with disabilities in the world is significantly growing. It is necessary to take concrete steps to make it so in Serbia as well.
\end{abstract}

Key words: PERSONS WITH DISABILITIES / COMBAT SPORTS / MARTIAL ARTS/ SERBIA

\section{INTRODUCTION}

It is common that a term adapted sport, or modified sport, indicates sports activities that are modified and adapted for persons with disabilities (Winnick, 1995). Combat sports, despite their highly prominent values are underrepresented among persons with disabilities in Serbia. However, by minimal modifications, these sports are becoming very accessible and interesting to the population of athletes with disabilities. The benefits of practicing martial sports are numerous, and the most important ones are: the promotion of physical fitness, greater mental strength and self-control, faster thought processes, relief from stress, concentration, respect for and understanding of oneself and others, self-confidence, socialization, a greater range of movements, and the practical method of self-defense, but also very nice fun. In Asia, martial arts have been used in medicine for more than 5,000 years. No wonder why, at some international hospitals, martial arts still have an important role in the treatment of chronically ill and disabled persons (Massey, 1999), and they are also applied in reducing inattention, impulsivity, hyperactivity and aggression 
in hyperactive children and children with attention disorders (Cooper, 2005).

This research is aimed at reviewing the martial arts and sports that are applied, or could be applied with the population of persons with disabilities, and to point out the importance of these sports for persons with disabilities who practice them. The historical method has been used in order to analyze the present state, and the descriptive method has been used in presenting the possibilities and the effects of practicing combat sports by persons with disabilities. The overview of martial arts and sports practiced by persons with disabilities has been made according to the review of the literature and the video materials related to this issue. The review of the situation in our country is based on visiting the clubs that are open for the training activities of persons with disabilities and whose programmes are adapted to this population.

\section{COMBAT SPORTS FOR PERSONS WITH DISABILITIES IN THE WORLD}

Currently, the programme of Paralympic Games includes only two sports, fencing and judo, in male and female competition. There is a good chance to find karate included in the programme at Paralympics in 2016, and there are similar ambitions in the case of taekwondo. Other combat sports are very little represented among the population of persons with disabilities, which is especially the case in Serbia. The reasons for weaker interest of persons with disabilities in other combat sports, should be sought in the fact that they are underrepresented among this population, and that these persons are not offered the possibility of organized practice of these sports. However, the situation around this problem is significantly different in the most developed countries. There are many places and clubs where people with disabilities have the opportunity to practice various martial arts and sports systematically and under expert supervision. Among other things, the therapy based on the blend of martial arts movements, taken from thai chi, Wushu kung fu, taekwondo, aikido, bagwa, moo doe and qigong, has been used for twenty years in ALTMED Clinic in Elk Grove, Illinois (Massey, 1999) .
The first combat sport actively practiced by persons with disabilities was wheelchair fencing. Wheelchair fencing was demonstrated for the first time at the Sports Games for persons with paraplegia in 1953 in Stoke Mandeville in England. In 1955 already, fencing in sabre discipline appeared as a part of the competitive programme in this competition, and in 1956 foil discipline was introduced as well. The same year the competition for women was held. Since the First Paralympic Games held in 1960 in Rome, fencing has been an essential part of regular programme. Unlike the competitive fencing for ablebodied population, wheelchair fencers are attached to a metal frame and they cannot move their wheelchairs. All other rules are very similar to fencing with motion, but the athletes are divided into the categories according to their mobility. In class A there are athletes with full trunk movement and good balance while sitting, and many of them can stand or even walk. In class B there are athletes with no leg movement and impaired trunk and balance functions while sitting, but they have full arm and hand movement. In class $C$ there are athletes with a disability in all four limbs and this class is not included in Paralymipc Games, but it is present in the programmes of World Championships.

Nowadays, the competitions are held for both individuals and teams and for both men and women. A team consists of three athletes, and each team has to have at least one athlete from class B. Men are competing in foil, sabre and epee events, and women participate in foil and epee events. Wheelchair fencing is highly developed in 26 countries, and there is a special interest of persons with lower limbs amputation, spinal cord injuries below T6 vertebra, spina bifida, cerebral palsy... Fencing is very stimulating for the development of coordination, the speed of movements and reaction, balance, mobility and stamina, and regarding high achievements, the athletes' longitudinal dimensions have an important role.

Judo was introduced at Paralymic Games in Seoul in 1988, whereas women competed for the first time in Athens in 2004. The blind (B1) and visually impaired athletes (B2 and B3) have the right to compete, and all three categories are competing in single, standard weight category. This sport was accepted by the International Blind Sports Federation (IBSA) in 1980, whereas judo for women was accepted by the same organization in 1995. The rules were taken from 
the International Judo Federation, with the modification that the athletes, before the referee gives the sign to start combat, have to get into a guard position. The equipment is a standard white or blue kimono, and blind competitors (B1) must have a red circle with diameter of $7 \mathrm{~cm}$ sewn on their sleeves on the shoulder. In addition, deaf competitors must have a blue circle on their back. Apart from individual competitions, team competitions are also held. There are five categories in male team competition $(66,73,81,90$ and +90 ), and each team has to have minimum 3 competitors, with at least two from B1. In female team competition there are four categories, and each team has to have at least two competitors, and at least one has to be B2. At the last IBSA World Games for visually impaired persons, held in Sao Paolo in 2007, 130 male and female athletes from more than 60 countries took part in judo competition. Judo as a Paralympic discipline is meant only for blind and visually impaired athletes, but this sport is also practiced by many other persons with disabilities. Glesser, Marguilles at al.(1992), teaching judo classes to the blind and visually impaired children, mentally hindered children or those with neuropsychiatric disorders, have reached the conclusion that judo possesses therapeutic, educational and recreational function, therefore they recommend that children and young people with disabilities should practice it. In some countries, for example in the city of Morgan in Australia specialised judo clubs for persons with mental retardation operate to a great extent (Whipp, 2010).

It is less known that wrestling has appeared two times in the programme of the Paralympic Games. At PG in Arnhem in 1980 the programme included wrestling for the visually impaired persons. In 10 weight categories, there were ten competitors registered, eight were from the USA and two from Canada. The medals were awarded, but no combats took place. At the next games, held in New York in 1984, there were 19 competitors from four countries, competing in nine weight categories. The Americans won seven gold and two silver medals, the Canadians won two gold and six silver ones, an Austrian won one silver and a Mexican one bronze medal. Since, at that time, it was insisted that at least 12 countries have to take part in each sport included in the PG programme, wrestling was removed from the programme, and instead of it, judo appeared in 1988 PG in Seoul. However, judo competitions for visu- ally impaired persons take place nowadays, and the rules are slightly different from the standard, in the sense of starting contact making. Apart from this, wrestling is very popular with the persons with the amputation of one or more limbs. The nature of the activity characteristic for wrestling is very stimulating itself for the development of strength, speed, balance, mobility coordination, so it is readily practiced by the amputees. In some cases, the amputees also compete in the competition of able-bodied population, and the particularly specific example is the one of twenty-year-old wrestler Dustin Carter, who, at the age of five, because of the meningococcal bacterial infection, had his both legs amputated, right bellow the hip joint, his left arm was amputated above the elbow, and his right arm was amputated right below the elbow. At the age of 14, this boy, at his school in Hillsborough, in the state of Ohio, started practicing wrestling. He gained international glory and became popular after the sixth of October 2009, when he won the silver medal at College Wrestling State Championship in Ohio, after the minimal defeat of 6:5 in the final combat.

Karate has not been included in the programme of Paralympic Games so far, although there are very good reasons and very favourable atmosphere in International Paralympic Committee for being so. It is realistic to expect karate included in the Paralympic Games programme, and according to some announcements, it may happen in 2016 in Rio de Janeiro. In many countries, kata competitions have already been set up, whereas there is not special interest in sparring competitions, so far. Within the WKF (3.11.2010) there are four competition categories: wheelchair athletes, athletes with intellectual disorders, athletes with amputations (group A2 and A4- above knee and below-knee leg amputation, group A6, A7 and A8- above-elbow and below- elbow arm amputation and the amputation of both arms, group A9- multiple amputations of legs and arms) athletes with cerebral palsy (only C7 and C8- hemiparesis and the lightest forms of paresis and atetosis). Some studies have justified that the karate training programme has considerably better effects on persons suffering from schizophrenia and other severe psychiatric disorders, compared to the methods of verbal therapy (Hasson, Kravetz, Roe, Rozencwaig \& Weiser, 2006).

Taekwondo is a sport having very positive effects on increasing anaerobic power and capacity, so 
it is eagerly recommended to persons with disabilities (Melhim, 2001). In many countries, especially the countries of Far East, taekwondo practicing represents a frequent choice of persons with disabilities. The First World Championship was held on the tenth of October 2009 in Baku, with the participation of 36 athletes from 16 countries. The Second World Championship was held on the tenth of May 2010 in St Petersburg with the participation of 65 athletes from 21 countries from five continents, mainly with the upper limbs amputations. These data point out that the interest in taekwondo of persons with disabilities is growing, along with the ambitions of the people in charge of this sport, so the chance to find this sport in the programme of Paralympic Games is realistic. So far, taekwondo competitions have been held only in the competitions of athletes with the upper limbs amputation. Some authors especially recommend it to hyperactive persons (Lichtenthal, 2009).

Boxing and kickboxing have not gained some special interest of persons with disabilities so far. However, the training technology of these sports implies, to a great extent, prop exercises and apparatus exercises (Cirkovic, 2002). Apparatus and prop exercises are available to almost everyone, and they are very stimulating for all motor activities, whereas the method of arranged, half-free and free sparring is recommended only to advanced practitioners. Thus, thirty-one-year-old Ron Man, who had his leg amputated after a car accident, practices kickboxing, and, apart from the rest, takes part in the mixed combat sports in the competition of able-bodied population. Baxter Himby was born in 1974 without his right forearm. At the age of 11 he started practicing sports and at the age of 17 he dedicated himself to kickboxing. The lack of an arm has not prevented him from winning many important titles in kickboxing, among which is a triumph in super welterweight category at Canada Kick-boxing Championship in 1996, and the title of world champion in super welterweight category in Thai boxing.

Thai-Chi-Chuan is an ancient Chinese martial art that nowadays enjoys the popularity with the eastern nations, but it is significantly widespread all over the world. This martial art is based on the balanced performance of the connected complexes of combat movements and breathing exercises, and the movements are dynamic and conceptualized according to the needs and abilities of persons with body disabilities. Very positive effects that this practice has on a greater diaphragm's mobility, better balance, increased movement amplitude and strength (Steven, 2010) have contributed to attracting great interest of persons with disabilities, and practicing of this art in wheelchairs was demonstrated in Beijing, just before the opening ceremony of the Paralympic Games. On this occasion, it was pointed out that thai-chi-chuan represents the simplest and the most rational way of improving physical abilities, health and mental energy of wheelchairs users. The researches at Emporia University have proven that practicing thai-chi-chuan of ten sets a day, for 15 weeks, results in decreasing the risk of falls due to balance loss, even for $50 \%$, and in lowering blood pressure as well (Cerrato, 1999). In physical sense, practicing thai-chi-chuan corresponds to walking at the speed of $6 \mathrm{~km} / \mathrm{h}$, whereas, in cognitive sense, it represents a meditation equivalent. The study including 33 persons with lower limbs osteoarthritis has shown that practicing thai-chi-chuan for an hour twice a week considerably improves selfefficiency, functional mobility and overall quality of these persons' lives (Hartman, 2000). The study performed in a sample of 2216 men and women has justified that practicing thai-chi-chuan at moderate intensity is useful for cardiovascular system, mental control, immune system, flexibility and balance, and it also increases strength and decreases the risk of falls, and with oxygen consumption not exceeding $55 \%$ of the maximum, it represents the exercise of moderate intensity (Li, 2001). The study including three persons, who had severe trauma brain injuries, has shown that thai-chi-chuan represents a very good means of improving their state. After 2 to 4 years of practicing, all three persons walked on their own, they rarely fell down, felt more safely, and improved their concentration and memory (Shapira, 2001). The study including 19 persons with multiple sclerosis has justified that the results of motor examinations and specific medical testing achieved by these persons after eight weeks of practicing thai-chi-chuan were significantly better than before they started practicing (Husted, 1999).

Bagwa is a martial art stemming from the first generation of Han dynasty ( $206 \mathrm{BC}-228 \mathrm{AD}$ ) and it is based on simultaneous rhythmic movements connected with breathing exercises. In its original form, this art consisted of more than 70 movements that 
represented the imitations of animals' moves, but today this number has significantly increased. Defensive and offensive movements are carried out in the circle with diameter of 6 or 12 meters, and bagwa has very positive effects on agility, speed, strength, vitality, longevity, inner and outer energy, immune system...No wonder why hundreds of people in the USA have started practicing bagwa during the last twenty years, and its form and rhythmic movements are especially attractive to elderly people and persons with disabilities.

Qigong or Chigong is an ancient Chinese form of exercise, described before more than 2500 years, that combines movement and meditation. This system of combat movements is very similar to thai-chi-chuan and it is a typical representative of so-called "inner martial arts". There are almost 400 styles, but about twenty of them are significant. These styles could be divided into dominantly medical (with positive effects on hypertension, diabetes, arthritis, degenerative spine changes, allergies, depression, anxiety, cancer,..), dominantly meditative (moral characteristics, longevity, self-enlightenment) and dominantly combat (punch resistance, breaking through solid objects). Because of its essence is the orientation towards oneself and one's own energy instead of the opponent's, it also raises great interest among elderly people and persons with disabilities.

Another martial art that raises pretty much interest of persons with disabilities is aikido. Aikido belongs to the so-called inner arts whose main idea is oriented more towards searching and reaching inner peace and full mind control, as well as the harmony of spirit and body than towards efficient and rational solving of conflict situations. Being so, aikido is very interesting to wider population of persons with disabilities, but its positive effect is especially emphasised among persons with impaired hearing. During training, dominant place belongs to visual learning of the technique, so that persons with impaired hearing have the possibility of complete devotion to practicing this art. Of course, other martial arts and sports are also very interesting to hearing impaired persons, and apart from world, continental, regional, and national championships, Silent Games, i.e., games for persons with impaired hearing, have especially great importance and long tradition. This competition started in 1924, and since 1961 when the Games took place in Helsinki, Greco-Roman wrestling and Free- style wrestling have been regular disciplines. At the last Silent games in 2009 in Taipei, the programme included judo, karate and taekwondo.

In a similar way, the martial art of Jiu Jitsu is very interesting to persons with disabilities. This art, unlike aikido, shows greater orientation towards concrete and efficient acting in different combat situations. Because of that, it does not only represent a very interesting means of improving motor abilities of persons with disabilities, but also a significant stimulus for improving psychological status of these persons. Dan Nederland, who suffered from polio as a child, is a great promoter of this and other martial arts as well. He has been practicing martial arts for 50 years already; he was a commander and an instructor in SWAT team, he survived Vietnamese war, and today he regularly holds seminars and presentation of martial arts. The essential idea of these presentations is the message addressed to persons with disabilities that they can do so much with strong will and persistence.

Since persons with disabilities are often "excluded" from the contacts with neighbours and fellow citizens, living very secluded and isolated life, they frequently become the victims of criminals' attacks. Frequent attacks on persons with disabilities, as well as the fact that these persons represent easy targets for attackers, led to forming the International Disabled Self-Defence Association (IDSA) by Jirgen Schmitt in 1966. This organization has launched the programme called "Defence Ability", based on the martial art of hapkido that implies a great number of different joint locks, pressing the sensitive or pressure points, gripping and ground combats and disarming techniques. This is just one of the organizations whose aim is to gather and systematically approach the martial arts training for persons with disabilities, and some authors have minutely elaborated typical self-defence situations from wheelchairs (Van de Sandt, 2004). In Casa Colina, the hospital for rehabilitation medicine, the self-defence training programme is a substantial part of the rehabilitation process for persons with spinal cord injuries, trauma brain injuries, brain stroke, spina biffida, cerebral palsy and polio, amputations, multiple sclerosis, as well as the blind, and the director of this programme is wheelchair user himself (Madorsky, 1989). 


\section{COMBAT SPORTS AND PERSONS WITH DISABILITIES IN SERBIA}

Persons with disabilities in Serbia are not, to a greater extent, involved in sports. When combat sports are considered, there is not much choice for persons with disabilities. The only combat sport which is recognized and accepted by the Paralympic committee of Serbia is judo for visually impaired persons. Though this sport is not massively represented, several clubs have given visually impaired persons the opportunity to build up and improve their sport skills along with able-bodied judo practitioners. And some clubs have also established special judo sections for visually impaired persons Thus, at the sports centre "Olimp", there is, as a part of its judo club, a section where visually impaired persons can practice judo according to a special programme. At the sports centre "Pinki", as a part of judo club "Mladost", a judo section for visually impaired persons has also been established. The number of this section's attendants is not quite big so far, but the new members are progressively joining it. At school for children with impaired hearing "Stefan Decanski", there is also a club where not only hearing impaired children, but also visually impaired ones can practice judo. However, the most impressive results in this sport have been achieved, so far, by visually impaired judo practitioner Branislav Viktorovic of judo club "Ruma", who won the fifth prize at European Championship for blind and visually impaired in 2003.

Within the range of combat sports, persons with disabilities have been recently given the opportunity to practice wheelchair fencing in Belgrade. Fencing club "Pobednik" provides the equipment and the frames needed for wheelchair fencing. Although some experts from this club, such as Miodrag Zelkovic, have gained international coaching reputation in wheelchair fencing, this sport has been 'opened' for persons with disability in this region for just few months. The number of those who have actively joined it is not quite big so far, but the beauty and attractiveness of this sport anticipates greater interest and massive representation.

Karate is also a sport that has gained the interest of persons with disabilities in this part of the world. There are many clubs open for children with disabilities, and karate club "Nipon" has gained wide reputation for including children with cerebral palsy in its programme successfully, and the extraordinary results have been achieved with the children with hemiparesis. Under the slogan "From handicap to handicap 2009" the first Serbian Karate Championship for persons with disabilities took place on the first of December 2009 in Novi Sad. In this competition, 26 athletes from five cities: Belgrade, Kovin, Zrenjanin, Klek, Becej took part. The competitions were held in the disciplines of kata and technique demonstration and in the categories of mild and moderate mental hinderance and body disability (SKF, 1.12.2009)

There is an opportunity for the blind and visually impaired persons to practice aikido in Belgrade. The number of involved practitioners is not quite big so far, but the fact that such practice has started and that practicing aikido is a concrete opportunity offered to this population is certainly significant. The master of aikido, Velibor Vesovic is in charge of the section for the blind and visually impaired in the municipality of Vracar.

Combat sports can be very interesting and useful for mentally hindered persons. There are karate and wrestling training sessions occasionally organized for the wards of the Institution for mentally hindered children and young people in Sremcica, and an exceptionally great popularity and interest in combat sports are recognized among these persons. At other homes and schools for persons with mental hinderance there are boxing training sessions organized occasionally and they mainly consist of apparatus exercises and half free sparring.

Among all combat sports, the greatest interest has been gained and by far the most impressive results achieved in wrestling for persons with impaired hearing. Although persons with impaired hearing are successfully engaged in the system of sport competitions of able-bodied population, their engagement in the system of adapted sport competition is more interesting in the context of this research. Because of that, the review and analysis of the participation of hearing impaired persons in the biggest and most important competition for this population, "Silent Games", frequently called Deaflympics, are given here as an illustration of the interest of hearing impaired persons in wrestling.

In Silent Games our wrestlers participated for the first time in Helsinki in 1961. The first medals in Greco-roman wrestling were won in Belgrade in 
1969. Since then, up to the 2005 Melbourne Games when our wrestlers participated for the last time in this competition, 32 medals have been won in wrestling (Table 1). Out of the total number of won medals, 25 were won in Greco-roman style (13 gold, 5 silver and 7 bronze) and 7 medals were won in free style ( 4 silver and 3 bronze). Individually, the greatest success was achieved by Rizvanovic Senad (3 gold and 1 bronze), Jakob Dusko (2 gold, 2 silver and 1 bronze) and Knezevic Mirko (2 gold and 1 silver medal). Apart from this competition, our hearing impaired wrestlers have achieved extraordinary success and won many medals at European and World Championships for hearing impaired persons. It is noticed that our hearing impaired wrestlers have achieved the greatest results in Greco-roman style which is quite predictable regarding the fact that Greco-roman wrestling of able-bodied population is also by far the most developed and the most popular wrestling style in Serbia (Kasum, Cirkovic, Jovanovic, 2010). However, we should not neglect the fact that in these big competitions, 7 medals were also won in free style. It is fully obvious that this fact contributes a lot to the greater representation and popularity of wrestling for hearing impaired population, but, in addition to that, so remarkable success significantly contributes to the growth of overall popularity and media's representation of the sport of wrestling in Serbia.

Table 1: The medals won by our wrestlers in Silent Games

\begin{tabular}{|c|c|c|c|c|c|c|c|c|c|}
\hline \multirow{2}{*}{ No. } & \multirow{2}{*}{ Cat. } & \multirow{2}{*}{$\begin{array}{l}\text { Last name, first name and } \\
\text { year of conquering medals }\end{array}$} & \multicolumn{3}{|c|}{ Greco Roman style } & \multicolumn{3}{|c|}{ Freestyle } & \multirow{2}{*}{$\Sigma$} \\
\hline & & & $\mathbf{I}$ & II & III & $\mathbf{I}$ & II & III & \\
\hline 1 & 57 & Nadj Janos, 1969., 73. & & 1 & 1 & & & 1 & 3 \\
\hline 2 & 70 & Radovic Miroslav, 1969. & & 1 & & & & & 1 \\
\hline 3 & +97 & Petrusevik Miroslav, 1969. & & & 1 & & & & 1 \\
\hline 4 & 48,57 & Jakob Dusko, 1973.,77.,81. & 2 & & 1 & & 2 & & 5 \\
\hline 5 & 52 & Radakov Jovo, 1973., 77. & 1 & 1 & & & 1 & & 3 \\
\hline 6 & 62,68 & Petrovic Stevan, 1973., 81. & 1 & & 1 & & & & 2 \\
\hline 7 & 62 & Sokolai Lazlo, 1977. & & 1 & & & & & 1 \\
\hline 8 & 68,74 & Knezevic Mirko, 1977,81. & 2 & & & & 1 & & 3 \\
\hline 9 & 82 & Kandra Mihailo, 1977. & & & 1 & & & & 1 \\
\hline 10 & 48 & Erdedi Sandor, 1981, & 1 & & & & & & 1 \\
\hline 11 & 82 & Vilmos Karolj, 1981. & 1 & & & & & & 1 \\
\hline 12 & 100 & Norandzic Bora, 1981. & & & & & & 1 & 1 \\
\hline 13 & 54 & Vajda Atila, 1997., 2001., 05. & 1 & 1 & & & & & 2 \\
\hline 14 & 58 & Rizvanović Senad, 1997.,2001.,05. & 3 & & & & & 1 & 4 \\
\hline 15 & 69 & Tot Peter, 1997.,2001.,05. & 1 & & 2 & & & & 3 \\
\hline Total & & & 13 & 5 & 7 & & 4 & 3 & 32 \\
\hline
\end{tabular}

At the first sight, it is noticed that there is no adequate range of opportunities for persons with disabilities in Serbia to practice combat sports. In Serbia, persons with disabilities practice fencing, judo and wrestling, as well as the martial art of aikido, but the only sport that has been really brought to life and that has gained significant interest among persons with disabilities is wrestling. The reasons for so strong in- terest in wrestling should be sought in the fact that hearing impaired persons practicing wrestling most frequently find their place and compete actively within the clubs of able-bodied population. Most of these athletes have achieved significant results in the competitions of able-bodied population, and the most important success is certainly the gold medal won in Greco-roman style by Senad Rizvanovic from Sub- 
otica at European Senior Championship in Helsinki, in 1989. These facts should serve as clear guidelines of the courses of popularizing and massive representation of martial arts and sports among persons with disabilities, but also as clear guidelines of the overall development of sports for persons with disabilities. One does not have to be very wise to understand that the best conditions and almost complete infrastructure are already present within the existing clubs and national federations of able-bodied population. Apart from the objects, apparatus and requisites, the clubs and national federations of able-bodied population most often fulfill the rest of accompanying elements: there are offices, employees, technical support.. On the other hand, it is much more difficult to provide necessary objects, apparatus and requisites only for persons with disabilities. For example, a wrestling club needs a gym, a mat, a lighting system, cameras and televisions, computers, offices, a telephone line, a fax, at least one permanently engaged operator... At this moment, it is pretty unrealistic to expect the fulfillment of all of those preconditions in order to open a wrestling club only for persons with disabilities. However, if already existing resources were used the situation would be much simpler and it would not require waiting any longer. Only the experts who will dedicate themselves to this task are needed to start the activities. On the other hand, the results achieved by the athletes with disabilities may concretely contribute to the overall popularity and media's representation of the sport. For example, the preparations of hearing impaired wrestlers may always be an interesting topic for print and electronic media. By the nature of journalism, it is common to announce every important competition of theirs in newspapers, and to give a final review after the competition. This kind of media interest does not differ from the common practice of sportive events coverage, and regarding very impressive results that are being achieved by our hearing impaired wrestlers on the international stage, an objective need to find out more about these sport heroes arises. For example, the story of Silent Games triple winner, Senad Rizvanovic from Subotica, is very interesting even to those who are not interested in wrestling at all. Such and many similar stories about other athletes will certainly contribute to greater popularity of the sport of persons with disabilities, but it will significantly affect the overall popularization of the sport practiced by those ath- letes. Scientific and professional literature dealing with the problem of sports people with disabilities is very poorly represented (Šiljak, Stefanović, Plakona, Kasum \& Avdibašić -Vukadinović, 2010), so that its publishing and distribution are an important step in improving the scientific and professional approach to sport of this population as well as martial arts in general. Such functional link between the sport of persons with disabilities and of able bodied population is not only typical of combat sports. In the case of all the sports practiced by persons with disabilities, it is possible and necessary to trace a mutual interest of national sport federations and existing clubs within those federations. On this basis, it is possible to develop the complete sport of persons with disabilities in a quicker and better way. Such approach will make it possible to find many other sports, instead of 12 currently accepted sport branches, under Serbian Paralympic Committee's wing. Thus, the number of athletes with disabilities will certainly grow, as well as these persons' opportunities to choose the most suitable sport.

\section{CONCLUSION}

Combat sports can be very useful for persons with disabilities, and by minimal corrections and modifications of rules and equipment, many combat sports are becoming available to this population. Apart from improving overall motor and health potential, orientation towards a combat sport also brings significant emotional experience to each practitioner, which is very important to persons with disabilities. Every physical activity brings benefits in the sense of increasing energy, mental capacities and concentration, and decreasing depression and stress. Mastering the martial arts requires time and persistence, so the effects of this practice are not noticeable as fast as in the case of practicing walking, running or swimming. However, martial arts and sports especially emphasize and build up the values such as responsibility and discipline, respect for a practicing partner, respect for a coach or instructor, aggression management and decreased stress sensitiveness, then tolerance, conflict avoidance, decreased provocation sensitiveness and cooperation. Essentially, by practicing a martial art, a person with disability is constantly 
fighting him or herself, thus actually building up his or her own abilities for fighting everyday problems in real life (Weiser, 1995). Exactly the fact that combat sports have great effect on overcoming psychological problems of persons with disabilities leads to their greater representation and popularity in the world. Application of the combat sport elements in fitness programs of led group makes these programs significantly and more interesting and, also, more effective for the general population practitioners (Stojiljković, Mandarić, Todorović, \& Mitić, 2010), and recently these programs are causing the increasing interest of people with disabilities.

Although combat sports and martial arts are underrepresented among persons with disabilities in Serbia, it is not very difficult to make them closer and available to this population. The fastest and most rational way of making these sports closer to population with disabilities implies the affiliation with national federations and existing combat clubs for able-bodied population. At these clubs, there already exists complete infrastructure, gyms for trainings and competitions, necessary apparatus and requisites, offices, telephone lines, whereas at national federations there are professionals who take care of legal regulative, inner organization, international correspondence... In such environment, it is very likely to find persons who are also ready for and interested in directing their own knowledge and energy towards improving the training technology and the system

\section{REFERENCES}

1. Cerrato, P.L. (1999). Tai Chi: A Martial Art Turns Therapeutic. RN Journal 62(2), 59-60.

2. Ćirkovic, Z. (2002). Sprave i rekviziti u boksu. [Devices and equipment in a boxing]. Beograd: SIA.

3. Gleser, J.M., Margulies, J.Y., V.M., Porat, S., Mendelberg, H., \& Wertman, E. (1992). Physical and psychosocial benefits of modified judo practice for blind, mentally retarded children: a pilot study. Perceptual and Motor Skills Journal, 74(3 Pt 1), 915-25.

4. Hartman, C.A. (2000). Effects of T'ai Chi Training on Function and Quality of Life Indicators of competition of this population. Understanding the problems of a particular sport or martial art will make it possible for these people to orientate, with additional education related to the specificity of training for persons with disabilities, towards the work with this population relatively quickly and successfully. Thus combat sports will become widely available to the population of persons with disabilities, so the considerable growth of the quantity and also the quality of combat sports practice of these persons can be expected soon. On the other hand, it should be expected that the popularity of sports, sport federations and clubs involving the athletes from the population of persons with disabilities will significantly grow. Only the fact that a national federation or a sport club has a section or a branch for persons with disabilities clearly points out their well organization and vitality. Possible sport results achieved will additionally actualize and intensify a good picture of these sportive societies, and it is also possible to obtain concrete financial satisfaction by the assessing system of massive representation, organization, achieved results, media's representation, accessibility and general impact on the quality of life as implied by the criteria for the categorization of sports and sport arts (Dragojlovic, 2009). There is no doubt that combat sports could represent an excellent choice of persons with disabilities, as well as of national sports federations and clubs. Mutual interest obviously exists, it should only be recognized.

in Older Adults with Osteoarthritis. Journal of the American Geriatrics Society, 48(12), 15531559.

5. Hasson, O. I., Kravetz, S., Roe, D., Rozencwaig, S. Weiser,, M. (2006). Qualitative assessment of verbal and non-verbal psychosocial interventions for people with severe mental illness. Journal of Mental Health,15(3): 343-353.

6. Husted, C. (1999). Improving Quality of Life for People with Chronic Conditions: The Example of Tai' Chi and Multiple Sclerosis. Alternative Therapies in Health and Medicine, 5(5), 70-74. 
7. Kasum, G., Ćirkovic, Z., \& Jovanović, S. (2010). Narodno i sportsko rvenje u Srbiji [National and sports wrestling in Serbia. Aktuelno u praksi, 9, 58-71.

8. KFS (1.12.2009). Novosti [News](3.12.2010). http://www.karateserbia.org/novosti.htm.

9. Kuper, E. (2005). The effects of martial arts on inattention, impulsivity, hyperactivity and aggression in children with attention-deficit/hyperactivity disorder: a single-subject multiplebaseline design across participants. Doctoral dissertation. Capella University.

10. Li, J.X. (2001). Tai Chi: Psychological Characteristics and Beneficial Effects on Health. British Journal of Sports Medicine, 35(3), 148-156.

11. Lichtenthal, G. (2009). How Can Martial Arts Benefit the Disabled? DC Taekwondo trainining, education, excellence (8.12.2010). http:// www.dctkd.org/library/papers/benefits-of-mafor-disabled.cfm.

12. Massey, P.B. (1999): Lasting Resolution of Chronic Thoracic Neuritis Using a Martial-Arts - Based Physical Therapy. Alternative Therapies in Health and Medicine, 5(3), 104.

13. Madorsky, J.G. (1989). Kung-Fu: Synthesis of Wheelchair Sport and Self-Protection. Archives of Physical Medicine and Rehabilitation, 70(6), 490-492.

14. Melhim, A.F. (2001). Aerobic and Anaerobic Power Responses to the Practice of Taekwon- Do. British Journal of Sports Medicine, 35(4), 231-234.

15. Dragojlović, U., Šebek, M., Mihajlović, M., Parežanin, D., Bugarčić, S., \&. Petrović, D. (2009). Pravilnici o kriterijumima za kategorizaciju sportova, misaonih sportskih igara $i$ sportskih veština. [Regulations on the criteria for the classification of sports, thought sports games and sports skills ]. Beograd: MOS SSS.
16. Shapira, M.Y. (2001). Tai Chi Chuan Practice as a Tool for Rehabilitation of Severe Head Trauma: 3 Case Reports. Archives of Physical Medicine and Rehabilitation, 82(9), 1283-1285.

17. Steven, L.W. (1996). Reducing Frailty and Falls in Older Persons: An Investigation of Tai Chi and Computerized Balance Training. Journal of the American Geriatrics Society, 44(5), 489-497.

18. Stojiljković, S., Mandarić, S., Todorović, K., \& Mitić, D. (2010). The Effects of the „Omnibus“ aerobics application on women's body composition. Physical Culture, 64(2): 59-67.

19. Šiljak, V., Stefanović, Dj., Plakona, E., Kasum, G., \& Avdibašić, N. (2010). Summer Paralympic games Phenomenon. Physical Culture, 64(2): 68-75.

20. Van De Sandt, R. (24.01.2004). Kurumaisu Jutsu: Wheelchair Techniques. Fighting Arts Com Magazine. http://www.fightingarts.com/content 02/wheelchair_tech_1.shtml.

21. Weiser, M. (1995). Psychotherapeutic Aspects of the"Martial Arts". American Journal of Psychotherapy, 49(1), 118-127.

22. Whipp, J. (2010). Official Grading of Judokas with an Intellectual Disability. FIGHT TIMES Fight Game e-Magazine ISSN 11768266 (8.12.2010). http://www.fighttimes.com/magazine/magazine. asp? article $=767$

23. Winnick, J.P. (1995). An Introduction to Adapted Physical Education and Sport. Adapted sport. In Winnick, J. P. (Ed.). Adapted Physical Education and Sport. Second edition (3-16). Champaign, Il.: Human Kinetics.

24. WKF (3. 11. 2010.). Karate for persons with disabilities. http://www.wkf-handicapped.com/en/ rules.html 
Горан Касум*

Страшо Глигоров**

796.8-056-26

Тања Настасић-Стошковић***

Стручни чланак

*Факултет спорта и физичког васпитања Београд, Универзитета у Београду

**СВР Скопље, Скопље, Македонија

***Клиничко-болнички центар „Др Драгиша Мишовић“, Београд

\title{
БОРИЛАЧКИ СПОРТОВИ ЗА ОСОБЕ СА ИНВАЛИДИТЕТОМ
}

\begin{abstract}
Сажетак
Термином прилагођени спорт у литератури се означавају спортске активности, модификоване и прилагођене особама са инвалидитетом. Упркос врло наглашеним вредностима, борилачки спортови нису довољно заступљени међу особама са инвалидитетом у Србији. Користи од бављења боричаким спортовима су вишеструке, а у поједним светским болницама, борилачки спортови и вештине већ имају значајну улогу у терапији трауматизованих и инвалидизираних лица. Тренутно се на програму параолимпијских игара налазе само два спорта, а то су мачевање и џудо, у мушкој и женској конкуренцији. Готово сигурно, на програму Параолимпијских игара наћиће се и карате, а сличне амбиције гаји и теквондо. Поред ових спортова, значајну заступљност и интересовање особа са инвалидитетом имају неке борилачке вештине, а пре свега аикидо, таи-чи-чуан и чигон. Разлоге слабијег интересовања за друге борилачке спортове и вештине, треба тражити у чињеници да они нису ни представљени овој популацији, нити им је понуђена могућност да се неким од тих спортова организовано баве. Опредељивање за неки борилачки спорт доноси велико освежење и снажан емотивни доживљај сваком вежбачу, а управо та чињеница има посебан значај за особе са инвалидитетом. У Србији, борилачки спортови немају неку велику масовност међу особама са инвалидитетом, а једино су рвачи са оштећеним слухом остваривали значајне успехе на међународној сцени. Са друге стране, популарност борилачких спортова међу особама са инвалидитетом у свету је у значајном порасту. Потребно је учинити конкретне кораке да тако буде и у Србији.
\end{abstract}

Кључне речи: БОРИЛАЧКЕ ВЕШТИНЕ / СРБИЈА / ПАРАОЛИМПИЈСКЕ ИГРЕ / ПРИЛАГОЪЕНИ СПОРТ

\section{УВОД}

Уобичајено је да се термином прилагођени спорт, или адаптирани спорт, подразумевају спортске активности које су модификоване и прилагођене особама са инвалидитетом (Winnick, 1995). Борилачки спортови, упркос својим врло наглашеним вредностима, нису превише заступљени међу особама са инвалидитетом у Србији. Ипак, уз минималне модификације, ови спортови постају врло доступни и интересантни за популацију спортиста са инвалидитетом. Кори- сти од бављења борилачаким спортовима су вишеструке, а посебно се издвајају: промоција физичке кондиције, већа ментална снага и самоконтрола, бржи мисаони процеси, ослобађање од стреса, концентрација, поштовање и разумевање себе и других, самоувереност, социјализација, већи опсег покрета, као и практичан метод самоодбране, али и врло лепа забава. У Азији, већ 5000 година борилачке вештине налазе примену у медицини. Зато не чуди што у поједним светским

Коресподенција са: Горан Касум, Универзитет у Београду, Факултет спорта и физичког васпитања, Београд, Благоја Паровића 156, e-mail: goran.kasum@fsfv.bg.ac.rs 
Касум Г., и сар., Борилачки спортови за особе са инвалидитетом ФИЗИЧКА КУЛТУРА 2011; 65 (1): 60-69

болницама, борилачке вештине и данас имају значајну улогу у терапији хронично оболелих и инвалидизованих лица (Mesi, 1999), а примењују се и за смањивање непажње, импулсивности, хипреактивности и агресивности код хиперактивне деце и деце са поремећајима пажње (Kuper, 2005).

Циљ овог истраживања је да направи преглед борилачких вештина и спортова који се примењују, или би се могли примењивати, у популацији особа са инвалидитетом, као и да укаже на значај ових спортова за особе са инвалидитетом које их упражњавају. Ради анализе постојећег стања кориштена је историјска метода, а у презентовању могућности и ефеката упражњавања борилачких спортова од стране особе са инвалидитетом, кориштена је дескриптивна метода. Преглед борилачких вештина и спортова којима се баве особе са инвалидитетом сачињен је на основу прегледа доступне литературе и видео материјала, који се односе на ову проблематику. Преглед стања у нашој земљи сачињен је на основу обиласка клубова који су отворени за тренажне активности особа са инвалидитетом и имају програме који су прилагођени овој популацији.

\section{БОРЕЊА ЗА ОСОБЕ СА ИНВАЛИДИТЕТОМ У СВЕТУ}

Тренутно се на програму параолимпијских игара налазе само два спорта, а то су мачевање и џудо, у мушкој и женској конкуренцији. Добри су изгледи да се и карате нађе на програму Параолимпијских игара 2016., а сличне амбиције гаји и теквондо. Остали борилачки спортови имају врло малу заступљеност у популацији особа са инвалидитетом, што је посебно наглашено у Србији. Разлоге овако слабе заитересованости особа са инвалидитетом за друге борилачке спортове, пре свега треба тражити у чињеници да они нису ни представљени овој популацији, нити им је понућена могућност да се неким од тих спортова организовано баве. Ипак, ситуација око ове проблематике значајно је другачија у најразвијениним земљама света. Тамо постоје многа места и клубови у којима је особама са инвалидитетом омогућено да, систематски и под стручним надзором, вежбају различте борилачке вештине и спортове. Између осталог, терапија заснована на мешавини борилачких покрета, преузетих из таи чи чуана, кунф фу ву шуа, теквондоа, аикидоа, багве моо дое и гигонга, већ двадесетак година користи се у Алтмед клиници у Ел Грову у држави Илиноис (Mesi, 1999).

Први борилачки спорт, којим су се особе са инвалидитетом активно бавиле, било је мачевање у колицима. Мачевање у колицима је први пут демонстрирано на Спортским играма особа са параплегијом, 1953. године у Сток Менедевилу у Енглеској. Већ 1955. године, као део такмичарског програма на овом такмичењу, нашла се борба у дисциплини сабља, а 1956. године и дисциплина мач. Исте године одржано је и такмичење за жене. Од Првих параолимпијских игара, 1960. године у Риму, мачевање је незаобилазни део сталног програма. За разлику од спортског мачевања опште популације, мачеваоци у колицима су причвршћени за метално постоље и не могу померати колица. Сва остала правила су веома слична мачевању са кретањем, али су такмичари подељени у категорије према својој покретљивости. Категорију А чине такмичари са потпуно покретним трупом и добром равнотежом током седења, а многи могу и да стоје или чак ходају. Категорију Б чине такмичари који немају покретне ноге и умањену поктретљивост трупа и равнотежу током седења, али имају потпуну покретљивост својих руку и шака. Категорија Ц су такмичари који немају покретљивост ногу нити потпуну покретљивост руку и/или шаке, и она није на програму параолимпијских игара, али је присутна на светским првенствима. Данас се такмичења одржавају у појединачној и екипној конкуренцији за мушкарце и жене. Тим чине по три такмичара, а свака екипа мора имати бар једног такмичара из категорије Б. Мушкарци се такмиче у дисциплинама флорет, мач и сабља, а жене флорет и мач. Мачевање у колицима је добро развијено у 26 земаља, а посебно је интересантно за особе са ампутацијама доњих екстремитета, повредама кичмене мождине испод пршљена Т6, спина бифидом, церебралном парализом... Мачевање веома стимулативно делује на развој координације, брзине покрета и реакције, равнотеже, покретљивости и издржљивости, а у смислу врхунских домета значајну улогу играју и лонгитудиналне димензије такмичара.

Џудо се на програму параолимпијских игара нашао 1988. године у Сеулу, док су се жене први пут такмичиле у Атини 2004. године. Право наступа имају слепи (Б1) и слабовиди такмичари (Б2 и Б3), а све три категорије се такми- 
че у јединственој конкуренцији, у стандардним тежинским категоријама. Од стране Светске асоцијације слепих и слабовидих особа - ИБСА, овај спорт је прихваћен 1980. године, док је иста организација џудо за жене прихватила 1995. године. Правила су преузета од Међународне џудо федерације, уз модификацију да такмичари, пре него што судија да знак за почетак борбе, морају успоставити гард. Опрема је класичан бели или плави кимоно, а потпуно слепи такмичари морају на рукаву, у пределу рамена, имати пришивен црвени круг пречника 7 цм. Уз то, глуви такмичари морају на леђима имати плави круг. Осим појединачне конкуренције, одржавају се и екипна такмичења. У мушкој екипној конкуренцији постоји пет категорија $(66,73,81,90$ и +90), а свака екипа мора имати минимум 3 такмичара, од чега барем двојица Б1. У женској екипној конкуренцији постоје 4 категорије, а свака екипа мора имати барем 2 такмичарке, а бар једна мора бити Б2. На последњим Светским играма особа оштећеног вида, које су 2007. године одржане у Сао Паолу, на такмичењу у шудоу учествовало је 130 такмичара и такмичарки из преко 60 земаља. Џудо као дисциплина параолимпијског програма предвиђен је само за слепе и слабовиде особе, али се овим спортом баве и многе друге особе са инвалидитетом. Глесер, Маргулиес и сарадници (1992) су, реализујући часове џудоа са слепом и слабовидом децом, децом која су ментално недовољно развијена или имају неуропсихијатријске поремећаје, дошли до закључка да џудо има терапеутску, образовну и рекреативну функцију, те га стога препоручују деци и омладини са инвалидитетом . У неким земљама, као на пример у граду Мурган у Аустралији, увелико функционишу специјализовани џудо клубови за особе са менталном недовољном развијеношћу (Whipp, 2010).

Мање је познато да се и рвање у два наврата нашло на програму параолимпијских игара. На ПОИ у Арнхему, 1980. године, на програму је било рвање за особе са оштећеним видом. У 10 тежинских категорија пријавило се укупно десет такмичара, осморица из УСА и двојица из Канаде. Медаље су подељене, али није одржана ни једна борба. На следећим играма, одржаним 1984. у Њујорку, било је укупно 19 такмичара из четири земље, у девет тежинских категорија. Американци су освојили седам златних и две сребрне медаље, Канађани две златне и шест сребрних,
Аустријанац једну сребрну а Мексиканац једну бронзану медаљу. Пошто се у то време инсистирало да у сваком спорту, који је на програму ПОИ, мора учествовати минимум 12 земаља, рвање је скинуто са програма, а уместо рвања, већ на ПОИ 1988. у Сеулу, нашло се џудо. Ипак, такмичења у рвању за особе са оштећеним видом одржавају се и данас, а правила се само незнатно разликују од оних стандардних, и то у смислу успостављања почетног контаката. Поред тога, рвање је врло популарно и међу особама којима је ампутиран један или више екстремитета. Сама природа активности која је карактеристична за рвање веома стимулативно утиче на развој снаге, брзине, равнотеже, координације окретности, па га особе са амутацијама врло радо упражњавају. У неким случајевима особе са ампутацијама се такмиче и у конкуренцији опште популације, а посебно је упечатљив пример двадесетједногодишњег рвача Дастина Картера, којем су у петој години живота, због инфекције бактеријом менингококус, обадве ноге ампутиране непосредно испод зглоба кука, лева рука ампутирана изнад лакта, а десна рука ампутирана непосредно испод лакта. У својој 14. години овај момак, у својој школи у Хилсбору у држави Охајо, почиње да тренира рвање. Светски познат и популаран постаје након 6.10.2009. године, када осваја сребрну медаљу на Првенству државе Охајо у „колеџ рвању“, након минималног пораза од 6:5 у финалној борби.

Карате се до сада још није нашао на програму параолимпијских игара, мада за то постоје веома добри разлози и доста повољна атмосфера у Међународном параолимпијском комитету. Реално је очекивати да ће се карате ускоро наћи на програму параолимпијских игара, а према неким најавама то би могло да буде 2016. године у Рио де Женеиру. У многим земљама већ се организују такмичења у катама, док за такмичења у борбама, за сада, не постоји неко веће интересовање. У оквиру WKF (3.11.2010.) постоје 4 такмичарске категорије: такмичари у колицима, такмичари са интелектуалним поремећајем, такмичари са ампутацијама (група A2 и A 4 - ампутација ноге изнад и испод колена, група A6, А7 и А8 - ампутација руке изнад и испод лакта, као и обе руке испод лакта, група А9 - комбиноване ампутације руку и ногу) и такмичари са церебралном парализом (само Ц7 и Ц8 - хемипарезе и најлакши облици пареза 
и атетоза). Нека истраживања потврдила су да програм вежбања каратеа остварује значајно бољи ефекат на особе са шизофренијом и другим тешким психијатријским поремећајима, него методе вербалне терапије (Hasson, Kravetz, Roe, Rozencwaig i Weiser, 2006).

Теквондо је спорт који изазива врло повољне ефекте на повећање анаеробне моћи и капацитета, па се најсрдачније препоручује особама са инвалидитетом (Melhim, 2001). У многим земљама, а посебно у земљама Далеког истока, тренирање теквондоа представља чест избор за особе са инвалидитетом. Прво светско првенство одржано је 10.06.2009. у Бакуу, уз учешће 36 такмичара из 16 земаља. Друго првенство света одржано је 10.05.2010. у Ст. Петербургу, уз учешће 65 такмичара из 21 земље са пет континената, углавном са ампутацијама горњих екстремитета. Ови подаци указују да интересовање за теквондо особа са инвалидитетом расте, као и амбиције људи који га воде да се овај спорт нађе на програму ПОИ нису нереалне. За сада, теквондо такмичења одржавају се само у категоријама лица са ампутацијама горњих екстремитета. Неки аутори га посебно препоручују хиперактивним особама (Lichtenthal, 2009).

Бокс и кикбокс нису, за сада, наишли на неко значајније интересовање код особа са инвалидитетом. Међутим, тренажна технологија ових спортова у значајном обиму предвића вежбе помоћу реквизита и рад на справама (Ћирковић, 2002). Вежбање на справама и помоћу реквизита доступно је готово свима, а врло стимулативно утиче на све моторичке способности, док се метод договореног, полуслободног или слободног спаринга препоручује само напредним вежбачима. Тако 31-годишњи Рон Ман, који је након саобраћајне несреће остао без ноге, вежба кикбокс и, између осталог, у конкуренцији редовне популације наступа на такмичењима мешовитих борилачких спортова. Бакстер Химби рођен je 1974. године без десне подлактице. Са 11 година почео је да се бави спортом, а са 17 се посветио кикбоксу. Недостатак руке му није засметао да освоји пуно значајних титула у кикбоксу, међу којима је тријумф у супервелтер категорији на Првенству Канаде у кикбоксу за 1996. годину, као и титула шампиона света супервелтер категорије у тајландском боксу.
Таи чи чуан је древна кинеска борилачка вештина, која данас ужива велику популарност међу источњачким народима, али је значајно распрострањена и по целом свету. Ова борилачка вештина заснива се на складном извођењу повезаних комплекса борилачких кретњи и вежби дисања, а покрети су динамични и конципирани у складу са потребама и могућностима особа са телесним инвалидитетом. Врло позитивни ефекти овог вежбања на већу покретљивост дијафрагме, бољи баланс, повећане амплитуде покрета и снаге (Steven, 2010), допринели су томе да ова вештина привуче врло велико интересовање особа са инвалидитетом, а вежбања ове вештине у инвалидским колицима демонстрирано је у Пекингу, непосредно пре свечаног отварања Параолимпијских игара. Том приликом је истакнуто да, за кориснике инвалидских колица, таи чи чуан представља најједноставнији и најрационалнији начин унапређења физичких способности, здравља и менталне енергије. Истраживања на Емпори универзитету доказала су да упражњавање таи чи чуана од 10 сетова вежби дневно, у трајању од 15 седмица, доводи до смањења ризика од пада услед губитка равнотеже за чак $50 \%$, као и до спуштања крвног притиска (Cerrato, 1999). У физичком смислу, упражњавање таи чи чуана одговара ходу брзином од 6 км/x, док у когнитивном смислу представља еквивалент медитацији. Студија на 33 особе са остеоартритисом на доњим екстремитетима, показала је да упражњавање таи чи чуана два пута седмично по један сат, значајно унапређује самоефикасност, функционалну покретљивост и укупан квалитет живота ових особа (Hartman, 2000). Студија рађена на 2216 мушкараца и жена потврдила је да је вежбање таи чи чуана умереним интензитетом корисно за кардиоваскуларни систем, менталну контролу, имуни систем, флексибилност и равнотежу, као и да повећава снагу и смањује ризик од падова, а пошто потрошња кисеоника не прелази 55\% од максималне, представља вежбање умереног интензитета (Ли, 2001). Студија на три особе, које су доживеле тешке трамутске повреде мозга, показала је да таи чи чуан представља врло квалитено средство у унапређењу њиховог стања. Након 2 до 4 године вежбања све три особе су ходале самостално, ретко падале, осећале се сигурније, те побољшале своју концентрацију и памћење (Shapira, 2001). Студија на 19 особа са 
мултиплекс склерозом потврдила је да су резултати моторичких тестова, као и специфичног медицинског теста, која су ова лица остварила након осам недеља вежбања таи чи чуана, била значајно боља него пре почетка вежбања (Husted, 1999).

Багва је борилачка вештина која потиче из прве генерације Династије Хан (206. пне - 228. не), и заснива се на синхронизованом ритмичном кретању повезаним са вежбама дисања. У свом изворном облику, ова вештина је имала преко 70 кретњи, које су представљале имитацију покрета животиња, али се данас тај број знатно повећао. Одбрамбени и нападачки покрети се одвијају у кругу пречника 6 до 12 метара, а багва врло повољно утиче на агилност, брзину, снагу, виталност, дуговечност, унутрашњу и спољашњу енергију, имуни систем... Зато не чуди што је у последњих 20 година, на стотине хиљада људи у САД почело да вежба багву, а њена форма и ритмички покрети посебно су привлачни за старије људе и особе са инвалидитетом.

Гигонг или чигонг је древни кинески облик вежбања, описан још пре 2500 година, који комбинује покрет и медитацију. Овај систем борилачких покрета, врло је сродан таи чи чуану, и типичан је представник такозваних „унутрашњих борилачких вештина“. Постоји близи 400 стилова, али је значајно око 20. Ове стилове је могуће поделити на доминантно здравствене (повољно утичу на хипертензију, дијабетис, артритис, астму, дегенеративне промене на кичми, алергије, депресије, анксиозност, рак..), доминантно медитативне (моралне карактеристике, дуговечност, самопросветљење) и доминантно борбене (отпорност на ударце, пробијање тврдих предмета). Због његове суштине, а то је окренутост ка себи и својој енергији уместо ка противнику, он такође наилази на велико интересовање код старијих људи и особа са инвалидитетом.

Још једна борилачка вештина, која наилази на солидно интересовање особа са инвалидитетом, јесте аикидо. Аикидо спада у такозване унутрашње вештине, односно вештине чија је основна идеја више окренута тражењу и постизању унутрашњег мира и потпуне контроле ума, као и хармоније духа и тела, него ефикасном и рационалном решавању конфликтних ситуација. Као такав, аикидо је врло интересантан за ширу популацију особа са инвалидитетом, али је његов позитиван утицај посебно апострофиран за особе оштећеног слуха. Приликом обуке, доминантно место припада визуелном учењу технике, тако да особе оштећеног слуха имају могућност потпуног предавања вежбању ове вештине. Наравно, и друге борилачке вештине и спортови врло су интересантни за особе оштећеног слуха, а осим светских, континенталних, регионалних и националних првенстава, посебно велики значај и дугу традицију имају Тихе игре, односно Игре особа оштећеног слуха. Ово такмичење је почело да се одржава још 1924. године а, од 1961. године и Игара у Хелсинкију, сталне дисциплине су рвање грчко римским и слободним стилом. На последњим Тихим играма, 2009. године у Таипеху, на програму су се нашли џудо, карате и теквондо.

На сличан начин, особама са инвалидитетом интересантна је и вештина џу-џуцу. Ова вештина, за разлику од аикидоа, има већу усмереност на конкретно и ефикасно дејствовање у различитим борилачким ситуацијама. Због тога представља врло интересантно средство усавршавања моторичких способности особа са инвалидитетом, али и значајан стимуланс унапређењу психолошког статуса ових особа. Дан Недерланд, који је као мали имао дечију парализу, велики је промотер ове, али и других борилачких вештина. Борилачким вештинама се бави већ 50 година, био је командир и инструктор у специјалним јединицама америчке војске SWAT, преживео је и вијетнамски рат, а данас широм света редовно држи семинаре и презентације борилачких вештина. Основна идеја ових наступа је порука особама са инвалидитетом да јаком вољом и упорношћу могу учинити јако пуно.

Пошто су особе са инвалидитетом често „склоњене“ од свакодневних контаката са комшијама и суграђанима, живећи доста повучено и изоловано, оне често постају предмет напада криминалаца. Учестали напади на особе са инвалидитетом, као и чињеница да напади на ова лица представљају врло лаку мету за нападаче, довели су до тога да Јирген Шмит 1996. године оснује Међународну асоцијацију за самоодбрану особа са инвалидитетом - IDSA. Ова организација је покренула програм под називом “Способност одбране”, која се заснива на борилачкој вештини хапкидо, која подразумева велики број различитих полуга, притисака на осетљиве тачке, захвата и борбе у партеру, као и разоружавајућих 
техника. Ово је само једна од организација која има за циљ да окупи и организовано приступи обучавању особа са инвалидитетом борилачким вештинама, а поједини аутори су до детаља разрадили типичне систуације самодбране из инвалидских колица (Van De Sandt, 2004). У Болници за рехабилитациону медицину Casa Colina у Америци, програм обуке самоодбране чини саставни део процеса рехабилтације особа са повредама кичмене мождине, трауматским повредама мозга, можданим ударом, спина бифидом, церебралном и дечијом парализом, ампутацијама, мултиплекс склерозом, као и слепих особа, а директор овог програма и сам је корисник инвалидских колица (Madorsky, 1989).

\section{БОРЕЊА И ОСОБЕ СА ИНВАЛИДИТЕТОМ У СРБИЈИ}

Особе са инвалидитетом у Србији нису у некој већој мери укључене у спорт. Када је реч о борилачким спортовима, овој популацији нису ни остављене могућности неког значајног избора. Једини борилачки спорт, који је препознат и прихваћен од стране Параолимпијског комитета Србије, јесте џудо за особе са оштећеним видом. Мада ни у овом спорту немамо неку масовност, неколико клубова је отворило могућност особама оштећеног вида да своје спортско умеће граде и усавршавају са џудистима опште популације, а неки клубови су отворили и посебну џудо секцију за особе оштећеног вида. Тако у Спортском центру „Олимп“, при тамошњем џудо клубу, постоји секција где, по прилагођеном програму, џудоом могу да се баве особе оштећеног вида. У Спортском центру „Пинки“, при ЏК „Младост“, отворена је џудо секција за особе оштећеног вида. Број полазника ове секције још није велики, али се постепено укључују и нови чланови. У школи за децу оштећеног слуха „Стефан Дечански“, такође егзистира клуб где се џудоом баве не само деца оштећеног слуха, већ и деца оштећеног вида. Ипак, до сада, највредније резултате у овом спорту, остварио је слабовиди џудиста Џудо клуба „Рума“ Бранислав Викторовић, који је на првенству Европе за слепе и слабовиде, 2003. године, освојио пето место.

Из репертоара борилачких спортова, особама са инвалидитетом у Београду од скоро је, осим џудоа, понуђена и могућност да се баве мачевањем у колицима. Мачевалачки клуб „По- бедник“ поседује опрему и платформе, потребне за мачевање у колицима. Мада су неки стручњаци из овог клуба, попут Миодрага Зељковића, стекли и међународну тренерску репутацију у мачевања у колицима, овај спорт је тек од пре неколико месеци „отворен“ за особе са инвалидиететом са нашег поднебља. Број оних који су се активно укључили за сада није велики, али лепота и атрактивност овог спорта наговештава наглашеније интересовање и већу масовност.

И карате је спорт који је, на нашим просторима, наишао на интересовање особа са инвалидитетом. Постоји више клубова који су отворени за децу са инвалидитетом, а КК „Нипон“" се већ надалеко прочуо по изузетно успешном укључивању у програм деце са церебралном парализом, а посебно добри резултати остварени су код деце са хемипарезом. Под називом „Од хендикепа до хендикепа 2009“, 1. децемра 2009. у Новом Саду одржано је и Прво карате првенство Србије за особе са инвалидитетом. На овом такмичењу учествовало је 26 такмичара из пет градова: Београда, Ковина, Зрењанина, Клека, Бечеја. Такмичења су одржана у дисциплинама кате и приказ техника, у категоријама лака и умерена ментална недовољна развијеност и телесни инвалидитет (КФС, 1.12.2009).

У Београду је слепим и слабовидим особама понуђена могућност да се баве и аикидоом. Број укључених вежбача за сада још увек није велик, али је свакако значајно што је таква пракса покренута и што је бављење аикидоом конкретна понуђена опција за ову популацију. Мајстор аикодоа Велибор Весовић води на Врачару секцију за слепе и слабовиде.

Борилачки спортови могу бити врло интересантни и корисни за особе са менталном недовољном развијеношћу. За штићенике Дома за децу и омладину ометену у менталном развоју „Сремчица“, повремено се организују тренинзи каратеа и рвања, а међу овим лицима се уочава изузетно велика популарност и интересовање за борилачке спортове. И у другим домовима и школама за лица са менталном недовољном равијеношћу, повремено се организују тренинзи бокса, који се углавном састоје од рада на справама и полуслободног спаринга.

Од свих борилачких спортова, највеће интересовање и убедљиво највреднији резултати, остварени су у рвању за лица оштећеног 
слуха. Мада се особе оштећеног слуха доста успешно укључују и у систем спортских такмичења редовене популације, за контекст овог истраживања интересантније је њихово укључивање у систем такмичења адаптираног спорта. Зато је, као илустрација заитересованости особа оштећеног слуха за рвање, овом приликом дат преглед и анализа учешћа особа оштећеног слуха на највећем и најважнијем такмичењу ове популације „Тихим играма“, често називаних и Олимпијске игре глувих.

На Тихим играма наши рвачи први пут су учествовали у Хелсинкију 1961. године. У Београду 1969. године, освојене су и прве медаље у рвању грчко - римским стилом. Од тада па до Игара у Мелбурну 2005. године, када су наши рвачи последњи пут учествовали на овом такмичењу, у рвању је освојено укупно 32 медаље (Табела 1). Од укупног броја медаља, 25 су освојене у грчко - римском стилу (13 златних, 5 сребрних, 7 бронзаних) и 7 у слободном стилу (4 сребрне и 3 бронзане). Појединачно, највише успеха имали су Ризвановић Сенад (3 златне и 1 бронзана), Јакоб Душко (2 златне, 2 сребрне и 1 бронзана) и Кнежевић Мирко (2 златне и 1 сребрна). Осим овог такмичења, наши рвачи оштећеног слуха су и на првенствима Европе и света за особе оштећеног слуха остварили изванредне успехе и освојили велики број медаља. Уочава се да су наши рвачи оштећеног слуха далеко вредније резултате остваривали у рвању грчко-римским стилом, што је сасвим очекивано када се има у виду чињеница да је у Србији, и у општој популацији, рвање грчко - римским стилом далеко најразвијенији и најпопуларнији облик рвања (Касум, Ћирковић, Јовановић, 2010). Ипак, не би требало занемарити чињеницу да је на овако великим тамичењима освојено 7 медаља и у слободном стилу. Сасвим je јасно да ова чињеница доприноси већој масовности и популарности рвања популације особа оштећеног слуха, али, поред тога, овако запажени успеси значајно доприносе и подизању укупне популарности и медијске заступљености рвачког спорта у Србији.

Табела 1 Медаље наших рвача на Тихим играма

\begin{tabular}{|c|c|c|c|c|c|c|c|c|c|}
\hline \multirow{2}{*}{ Рб } & \multirow{2}{*}{ Кат } & \multirow{2}{*}{$\begin{array}{l}\text { Име и презиме и година } \\
\text { освојања медаље }\end{array}$} & \multicolumn{3}{|c|}{ Грчко римски стил } & \multicolumn{3}{|c|}{ Слободни стил } & \multirow{2}{*}{ Укупно } \\
\hline & & & $\mathbf{I}$ & II & III & $\mathbf{I}$ & II & III & \\
\hline 1 & 57 & Нађ Јанош, 69, 73 & & 1 & 1 & & & 1 & 3 \\
\hline 2 & 70 & Радовић Мирослав, 69 & & 1 & & & & & 1 \\
\hline 3 & +97 & Петрушевик Мирослав69 & & & 1 & & & & 1 \\
\hline 4 & 48,57 & Јакоб Душко 73,77,81 & 2 & & 1 & & 2 & & 5 \\
\hline 5 & 52 & Радаков Јово, 73, 77 & 1 & 1 & & & 1 & & 3 \\
\hline 6 & 62,68 & Петровић Стеван, 73, 81 & 1 & & 1 & & & & 2 \\
\hline 7 & 62 & Соколаи Ласло, 77 & & 1 & & & & & 1 \\
\hline 8 & 68,74 & Кнежевић Мирко 77,81 & 2 & & & & 1 & & 3 \\
\hline 9 & 82 & Кандра Михаило, 77 & & & 1 & & & & 1 \\
\hline 10 & 48 & Ердеди Шандор, 81 & 1 & & & & & & 1 \\
\hline 11 & 82 & Вилмош Карољ, 81 & 1 & & & & & & 1 \\
\hline 12 & 100 & Норанџић Бора, 81 & & & & & & 1 & 1 \\
\hline 13 & 54 & Вајда Атила, 97, 01, 05 & 1 & 1 & & & & & 2 \\
\hline 14 & 58 & Ризвановић Сенад 97,01,05 & 3 & & & & & 1 & 4 \\
\hline 15 & 69 & Тот Петер, 97, 01, 05 & 1 & & 2 & & & & 3 \\
\hline \multicolumn{2}{|c|}{ УКУПНО } & & 13 & 5 & 7 & & 4 & 3 & 32 \\
\hline
\end{tabular}

Већ на први поглед уочава се да у Србији не постоји адекватан репертоар могућности да се особе са инвалидитетом баве борилачким спортовима. У Србији, од борилачких спортова, особе са инвалидитетом упражњавају мачевање, џудо и рвање, као и борилачку вештину аикидо, а једини спорт који је заиста заживео и наишао на значајно интересовање особа са инвалидитетом јесте рвање. Разлоге овако наглашеног интересовања за рвање треба тражити 
у чињеници да особе оштећеног слуха, које се баве рвањем, најчешће проналазе своје место и активно се такмиче у оквиру клубова опште популације. Већина ових такмичара остваривала је значајне резултате и на такмичењима опште популације, а свакако најзначајнији успех јесте златна медаља на Сениорском првенству Европе, коју је у грчко-римском стилу, 1989. године у Ослу, освојио Суботичанин Сенад Ризвановић. Ове чињенице би требале да послуже као јасан путоказ праваца популаризације и омасовљења борилачких вештина и спортова међу особама са инвалидитетом, али и као јасне смернице развоја укупног спорта особа са инвалидитетом. Не треба бити много мудар да би се схватило да најбољи услови и скоро комплетна инфраструктура већ постоји у оквиру постојећих клубова и националних савеза опште популације. Поред објеката, справа и реквизита, клубови и национални савези опште популације, најчешће, испуњавају и остале пратеће елементе: имају канцеларије, запослена лица, техничку подршку... Са друге стране, далеко је теже обезбедити потребне објекте, справе и реквизите само за особе са инвалидитетом. Примера ради, једном рвачком клубу потребни су сала, струњача, семафори, камере и телевизори, рачунари, канцеларија, телефонска линија, факс, бар један стално ангажовани оперативац... У овом тренутку, доста је нереално очекивати испуњење свих ових предуслова, како би се отворио један рвачки клуб само за особе са инвалидитетом. Међутим, ако се користе већ постојећи ресурси, ствар је доста једноставнија и не захтева било какво чекање. Потребна су само стручна лица која ће се посветити овом послу и са активностима може да се почне. Са друге стране, резултати које постижу спортисти са инвалидитетом могу конкретно допринети укупној популарности и присутности у медијима конкретног спорта. Примера ради, припреме рвача оштећеног слуха увек могу бити интересантна тема за писане и електронске медије. По природи новинарске праксе, уобичајено је да се свако њихово значајније такмичење најави у новинама, да током такмичења буду објављене информације о оствареним резултатима, као и да након завршетка такмичења буде дат завршни коментар. Оваква врста медијске пажње не одступа од уобичајене праксе праћења спортских догађаја, $a$, с обзиром на врло импресивне резултате које наши рвачи оштећеног слуха постижу на међународној сцени, отвара се објективна потреба да се о тим спортским јунацима сазна и нешто више. Примера ради, прича о троструком победнику Тихих игара, Суботичанину Сенаду Ризвановићу, веома је интересантна чак и за оне које рвање уопште не прате. Таква и сличне приче о другим спортистима сигурно ће допринети већој популарности спорта особа са инвалидитетом, али ће значајно утицати и на укупну популаризацију спорта којим се ти спортисти баве. Научна и стручна литература која се бави проблематиком спорта особа са инвалидитетом је веома слабо заступљена (Шиљак, Стефановић, Плакона, Касум и Авдибашић -Вукадиновић, 2010), тако да се њеним публиковањем и дистрибуирањем чини значајан корак у унапређењу научног и стручног приступа спорту ове популације али и борилачким спортовима уопште. Оваква функционалана повезаност спорта особа са инвалидитетом и опште популације није типична само за борилачке спортове. За све спортове, којима се особе са инвалидитетом баве у Србији, могуће је и потребно пронаћи обострани интерес са националним спортским савезима и постојећим клубовима у оквиру тих савеза. На овако успостављеним основама могуће је брже и квалитетније развијати комплетан спорт особа са инвалидитетом. Овакав приступ омогућиће и да се под окриљем Параолимпијског комитета Србије, уместо тренутно прихваћених 12 спортских грана, ускоро нађу и многи други спортови. Тиме ће се сигурно повећати број спортиста са инвалидитетом, али и могућност ових особа да одаберу спорт који им највише одговара.

\section{ЗАКЉУЧАК}

Борилачки спортови могу бити врло ко= рисни за особе са инвалидитетом, а уз минималне корекције и модификације правила и опреме, многи борилачки спортови постају врло доступни овој популацији. Осим унапређења укупног моторичког и здравственог потенцијала, опредељивање за неки борилачки спорт доноси и снажан емотивни доживљај сваком вежбачу, што за особе са инвалидитетом има посебан значај. Свака физичка активност доноси бенефите у смислу повећања енергије, менталних капацитета и концентрације, те смањивања депресије и стреса. Овладавање борилачким вештинама захтева време и упорност, 
па су ефекти овог вежбања приметни нешто спорије него када се упражњава ходање, трчање или пливање. Међутим, борилачке вештине и спортови посебно наглашавају и изграђују вредности као што су одговорност и дисциплина, поштовање партнера за вежбање, поштовање тренера и инструктора, контрола агресивности и смањена осетљивост на стрес, те толерантност, избегавање сукоба, мања осетљивост на провокације и спремност на сарадњу. У суштини, вежбајући неку борилачку вештину, особа са инвалидитетом се стално бори против самога себе, и тиме заправо унапређује своје способности за борбу са свакодневним проблемима у реалном животу (Weiser, 1995). Управо чињеница да борилачки спортови имају наглашен ефекат на превазилажење психолошких проблема особа са инвалидитетом, доводи до њихове све веће масовности и популарности у свету. Примена елемената борења у програмима групно вођеног фитнеса чини ове програме значајно интересантнијим и ефикаснијим за вежбаче опште популације (Стојиљковић, Мандарић, Тодоровић и Митић, 2010), а у новије време ови програми изазивају и све веће интересовање особа са инвалидитетом.

Мада су борилачки спортови и борилачке вештине слабо присутни код особа са инвалидитетом у Србији, није потребан велики напор како би се они приближили и учинили доступним овој популацији. Најбржи и најрационалнији начин приближавања ових спортова популацији особа са инвалидитетом упућује на повезивање са националним савезима и постојећим борилачким клубовима редовне популације. При овим клубовима већ постоји комплетна инфраструктура, сале за тренинге и такмичења, потребне справе и реквизити, канцеларије, телефонске линије, док у националним савезима постоје професи-

\section{ЛИТЕРАТУРА}

1. Van De Sandt, R. (24.01.2004). Kurumaisu Jutsu: Wheelchair Techniques. Fighting Art.Com Magazine. http://www.fightingarts.com/content 02/wheelchair_tech_1.shtml. онална лица која воде бригу о правној регулативи, унутрашњој организацији, међународној коресподенцији... У оваквом окружењу, врло вероватно, наћи ће се и лица која су спремна и заинтересована да своје знање и енергију усмере у правцу унапређења тренажне технологије и система такмичења ове популације. Познавање проблематике конкретног спорта или борилачке вештине, омогућиће овим људима да се, уз додатно образовање везано за специфичности тренинга особа са инвалидитетом, релативно брзо и успешно преоријентишу на рад са овом популцијом. На тај начин ће се борилачки спортови учинити врло доступним популацији особа са инвалидитетом, па је за очекивати да се у догледно време значајно повећа квантитет али и квалитет бављења ових особа борилачким спортовима. Са друге стране, треба очекивати да ће популарност спортова, спортских савеза и клубова, који буду анимирали спортисте из популације особа са инвалидитетом, значајно порасти. И сама чињеница да један национални савез или спортски клуб имају секцију или огранак за особе са инвалидитетом јасно указује на њихову добру организованост и виталност. Евентуални остварени спортски резулати додатно ће актуелизовати и интензивирати добру слику о овим спортским колективима, а кроз систем вредновања масовности, организованости, остварених резултата, медијске заступљености, приступачности и опшег утицаја на квалитет живота, како то предвиђају критеријуми за категоризацију спортова и спортских вештина, могуће је остварити и конкретну финансијску сатисфакцију (Драгојловић и сар., 2009). Нема сумње да борења могу представљати одличан избор особа са инвалидитетом, али и националних спортских савеза и клубова. Обострани интерес дефинитивно постоји, само га треба препознати.
2. Gleser, J.M., Margulies, J.Y., Nyska, M., Porat, S., Mendelberg, H., Wertman, E. (1992). Physical and psychosocial benefits of modified judo practice for blind, mentally retarded children: a pilot study. Perceptual and Motor Skills Journal, 74(3 Pt 1), 915-25. 
3. Драгојловић, У, Шебек, М., Михајловић, М., Парежанин, Д., Бугарчић, С. и Петровић, Д. (2009). Правилници о критеријумима за категоризачију спортова, мисаоних спортских игара и спортских вештина. Београд: МОС ССС.

4. Касум, Г., Ћирковић, 3. Јовановић, С. (2010). Народно и спортско рвање у Србији. Актуелно у пракси, 9, 58-71.

5. КФС (1.12.2009). Новости (3.12.2010). http:// www.karateserbia.org/novosti.htm.

6. Kuper, E. (2005). The effects of martial arts on inattention, impulsivity, hyperactivity and aggression in children with attention-deficit/hyperactivity disorder: a single-subject multiplebaseline design across participants. (Doctoral dissertation.) Capella University.

7. Li, J.X. (2001). Tai Chi: Psychological Characteristics and Beneficial Effects on Health. British Journal of Sports Medicine, 35(3), 148-156.

8. Lichtenthal, G. (2009). How Can Martial Arts Benefit the Disabled? DC Taekwondo trainining, education, excellence (8.12.2010). http:// www.dctkd.org/library/papers/benefits-of-mafor-disabled.cfm

9. Massey, P.B. (1999): Lasting Resolution of Chronic Thoracic Neuritis Using a Martial-Arts - Based Physical Therapy. Alternative Therapies in Health and Medicine, 5(3), 104.

10. Madorsky, J.G. (1989). Kung-Fu: Synthesis of Wheelchair Sport and Self-Protection. Archives of Physical Medicine and Rehabilitation, 70(6), 490-492.

11. Melhim, A.F. (2001). Aerobic and Anaerobic Power Responses to the Practice of TaekwonDo. British Journal of SportsMedicine, 35(4), 231-234.

12. Shapira, M.Y. (2001). Tai Chi Chuan Practice as a Tool for Rehabilitation of Severe Head Trauma: 3 Case Reports. Archives of Physical Medicine and Rehabilitation, 82(9), 1283-1285.

13. Steven, L.W. (1996). Reducing Frailty and Falls in Older Persons: An Investigation of Tai Chi and Computerized Balance Training. Journal of the American Geriatrics Society, 44(5), 489-497.
14. Стојиљковић, Мандарић, Тодоровић и Митић (2010). Ефекти примене „омнибус“ аеробика на телесну композицију жена. Физичка култура, 64(2): 59-67.

15. Ћирковић, 3. (2002). Справе и реквизити у боксу. Београд: СИА.

16. Hartman, C. A. (2000). Effects of T'ai Chi Training on Function and Quality of Life Indicators in Older Adults with Osteoarthritis. Journal of the American Geriatrics Society, 48(12), 15531559.

17. Hasson, O. I., Kravetz, S., Roe, D., Rozencwaig, S. Weiser,, M. (2006). Qualitative assessment of verbal and non-verbal psychosocial interventions for people with severe mental illness. Journal of Mental Health,15(3): 343-353.

18. Husted, C. (1999). Improving Quality of Life for People with Chronic Conditions: The Example of Tai' Chi and Multiple Sclerosis. Alternative Therapies in Health and Medicine, 5(5), 70-74.

19. Cerrato, P. L. (1999). Tai Chi: A Martial Art Turns Therapeutic. RN Journal 62(2), 59-60.

20. Шиљак, Стефановић, Плакона, Касум и Авдибашић-Вукадиновић (2010). Феномен Летњих параолимпијских игара. Физичка култура, 64(2): 68-75.

21. Weiser, M. (1995). Psychotherapeutic Aspects of the"Martial Arts”. American Journal of Psychotherapy, 49(1), 118-127.

22. Whipp, J. (2010). Official Grading of Judokas with an Intellectual Disability. FIGHT TIMES Fight Game e-Magazine ISSN 11768266 (8. 12. 2010). http://www.fighttimes.com/magazine/ magazine. asp?article $=767$

23. Winnick, J. P. (1995). An Introduction to Adapted Physical Education and Sport. Adapted sport. In Winnick, J. P. (Ed.). Adapted Physical Education and Sport. Second edition (pp. 3-16). Champaign, Il.: Human Kinetics.

24. WKF (3. 11. 2010.). Karate for persons with disabilities. http://www.wkf-handicapped.com/en/ rules.html

Примљен: 14.12.210. Прихваћен: 26.4.2011. 